For citation: Yesilyurt O. \& Selamzade F. (2020). Measuring CIS Health Systems Using the Stochastic Frontier Analysis (SFA). Ekonomika Regiona [Economy of Region], 16(1), 59-68

https://doi.org/10.17059/2020-1-5

UDC: 332

O. Yesilyurt, F. Selamzade

Muş Alparslan University (Muş, Turkey; e-mail: f.salamov@alparslan.edu.tr)

\title{
MEASURING CIS HEALTH SYSTEMS USING THE STOCHASTIC FRONTIER ANALYSIS (SFA) ${ }^{1}$
}

The Commonwealth of Independent States (CIS) was founded in 1991 after the dissolution of the Union of Soviet Socialist Republics (USSR). The member countries are Azerbaijan, Belarus, Armenia, Kazakhstan, Kyrgyzstan, Moldova, Uzbekistan, Russia, Tajikistan, Turkmenistan and Ukraine. Turkmenistan resigned its full membership status in 2005 and changed its CIS standing to observer member. Drawing on the methods of Least Squares and Maximum Likelihood Estimation of Stochastic Frontier Analysis, we made estimations to find efficiency scores in the health sector by using the data for the period from 2010 to 2015 of the countries that are members of the Commonwealth of Independent States. In the study, we used various factors as dependent and independent variables, including the number of doctors, medical personnel and hospital beds per ten thousand people, the life expectancy at birth, under-five mortality rate and the incidence of tuberculosis per one hundred thousand people. We have found that such factor as the number of doctors effectively influences reduction of the under-five mortality rates and the incidence of tuberculosis, while the factor "the number of hospital beds" is not very effective. Finally, for the CIS countries we made recommendations to popularize the health insurance, to change the old Soviet form of health management in public hospitals, and to implement liberal socio-economic policies.

Keywords: CIS, Efficiency, Stochastic Frontier Analysis, Least Squares, Maximum Likelihood Estimation, SocioEconomic Policies, Health Systems, Productivity, Number of Doctors, Number of Nurses

\section{Introduction}

The international comparison of health system performances has attracted attention of various researchers. In the countries of the Commonwealth of Independent States (CIS) as well as in many countries of the world, the health sector constitutes the largest service sector. The average health expenditures of the CIS countries had been at the rate of $3 \%$ of gross domestic product $(G D P)$ in 2010-2015. The World Health Organization points out that a share of a country's health spending should be at least $5 \%$ of that country's GDP and that developing or underdeveloped countries make it a target [1, p. 105]. Among the CIS countries, Moldova (5.1\%) has the highest share of the state's GDP allocated to health expenditures, while Azerbaijan has the lowest (1.3\%). Especially, hospitals use a significant proportion of total health expenditure. Therefore, analysis of the health sector significant contributes to the comparison of health system performances.

Measurement of efficiency of health systems is one of the main indicators for determining service performance and efficient use of resources. Even though there are many studies assessing and comparing the efficiency of health, the number of stud-

\footnotetext{
${ }^{1}$ (c) Yesilyurt O. \& Selamzade F. Text. 2020.
}

ies analysing the efficiency of health systems by using data from the CIS countries is very low. The lack of studies analysing the efficiency of health system for the CIS countries is cause by difficulties in obtaining the necessary data for a comprehensive international comparison. The academic studies generally use Data Envelopment Analysis (DEA) technique, which is non-parametric. This research was conducted drawing on the method of Stochastic Frontier Analysis in order to contribute to the academic field. In the study, efficiency was assessed with the help of Least Squares and Maximum Likelihood Estimation using the data for the period from 2010 to 2015. In this context, it is aimed to examine the effects of various factors, such as the number of doctors, medical personnel and hospital beds per ten thousand people on the life expectancy at birth, under-five mortality rate and the incidence of tuberculosis per hundred thousand people per year.

\section{Methods and Theory}

In the parametric approach, which is a boundary one, measurement of efficiency is carried by using multiple regression techniques in which the single output is studied with multiple inputs, and the parameters in the function are estimated. In this study, we attempted to determine the effects 
of inputs, which are the independent variables on the changes in the output, which is the dependent variable. Inefficient production components were considered as deviating from the frontier. The method is believed to have a random error, however, it is observed that at the fully efficient production frontier the error is zero [2, p. 87].

The deviation from determined production and/or cost limit can be caused by the random effects as well as by inefficiency. Farrell (1957) [3] was the first scientist who focused on the measurement and importance of the efficiency. In order to find the deviation occurring due to inefficiency, it is required to separate the reasons of random effects and inefficiency. Efficiency as an effective deviation in the context of stochastic frontier analysis became the subject of the studies about 50 years ago. Results of the conducted studies are described in the works of both foreign and Russian scientists $[4,5,6,7,8,9,10,11,12,13$, $14,15]$. The gap was filled with the development of the SFA method under the leadership of Aigner, Lovell and Schmidt (1977) [17] and Meeusen and Van Den Broeck (1977) [18].

To ensure simplicity of classical economics calculations, the maximization of single output " $y$ " in Cobb-Douglas production function is carried by using $x_{1}$ and $x_{2}$ inputs [19, p. 82].

$$
y=a x_{1}^{\alpha_{1}} x_{2}^{\alpha_{2}} e^{v} .
$$

This function determines the technological (specific) efficiency limit, and the observations must comply with it. Statistical errors should be allowed for these calculations. The limits for the observed parameters $\alpha, \alpha_{1}$ and $\alpha_{2}$ (estimated using the data) will only be defined as stochastic [20, p.11]. The number $e$ is a Euler's irrational number, calculated by the inefficiency of a firm. [21, p. 23, 22 , p. 154]. These statistical errors are indicated by $v$ in formula (1). Statistical error terms subsequently were added to each y value by selecting from $v_{i} \sim$ iid $N\left(0, \sigma_{v}^{2}\right)$ distributions by sampling. iid (independent, identically, distributed) means independent, zero mean and constant variance distribution. After that, the "efficient" $x_{1}, x_{2}$ inputs were replaced by new inputs as shown below [19, p. 82];

$$
\hat{x}_{1}=x_{1} e^{v_{1}} ; \hat{x}_{2}=x_{2} e^{v_{2}},
$$

here $v_{1}, v_{2} \geq 0$.

The assumption that the inefficiencies comply with either exponential or semi-normal distributions is valid. Therefore, the distributions $\left(0, \sigma_{v 1}^{2}\right.$; $0, \sigma_{v 2}^{2}$ ) have been changed in formula (1).

$$
y=\beta \hat{x}_{1}^{\beta_{1}} \hat{x}_{2}^{\beta_{2}} e^{v},
$$

here $\hat{x}_{1} \geq x_{1}$ and $\hat{x}_{2} \geq x_{2}$ were accepted and the actual observed inputs were changed. In order to make an estimation, the formula (3) was changed by assuming the following log-linear form.

$$
\ln y=\beta_{0}+\beta_{1} \ln \hat{x}_{1}+\beta_{2} \ln \hat{x}_{2}+v,
$$

here, $\beta$ s take place in the formula as predictors for $\alpha, \alpha_{1}$ and $\alpha_{2}$, which are the actual production function parameters in formula (1). Cooper and Tone (1997) [19] used "the error occurrence" version of the SFA method in their studies.

$$
\ln y=\beta_{0}+\beta_{1} \ln \hat{x}_{1}+\beta_{2} \ln \hat{x}_{2}+v-u .
$$

$(v-u)$ was added to the formula (4), where $v$ is the $N\left(0, \sigma_{\mathrm{v}}^{2}\right)$ distributed random variable that is supposed to be distributed independently, and where $u(u \geq 0)$ is the random variable that measures the technical inefficiency that does not take a negative value. Terminology refers to occurrence of $u \geq 0$ as to "abandoned outputs" [23, p. 24]. Generally, it is assumed that each $v_{i}$ random variable is distributed independently from each ui random variable and that the two error terms are unrelated to the explanatory variables. In the stochastic frontier analysis, assumptions are made for the random variable as follows [24, pp. 32-33]:

$$
E\left(v_{i} \mid X_{i}\right)=0
$$

In the value $x$ given in the formula (6), the mean of the detrimental term is zero. Thus, the noise component $v$ is assumed to have properties that are identical to those of the noise component in the classical linear regression model. The inefficiency component has similar properties except it has a nonzero mean (because $u_{i} \geq 0$ ). When homoscedasticity is discussed for the term $v_{i}$, the variance of $v_{i}$ for $X_{i}$ is regarded as constant and positive. This assumption is expressed as follows [25, p. 245]:

$$
\begin{gathered}
\text { variance }\left(v_{i} \mid X_{i}\right)=E\left[v_{i}-E\left(v_{i}\right) \mid X_{i}\right]^{2}= \\
=E\left(v_{i}{ }_{i} \mid X_{i}\right)=\sigma^{2}{ }_{v}
\end{gathered}
$$

The following assumptions about distribution were used for getting the maximum likelihood estimation of the stochastic production limit [9, p. 28]. These assumptions refer to the distribution in the form of $u_{i} \sim$ iid $N+\left(0, \sigma_{u}^{2}\right)$ series together with $v_{i} \sim$ iid $N\left(0, \sigma_{v}^{2}\right)$ described above. In the normal distribution of the translog discrete, it refers to mean value $u$ and the distributions are assumed as $v_{i} \sim$ iid $N\left(\mu, \sigma_{v}^{2}\right)$ and $u_{i} \sim$ iid $N+\left(\mu, \sigma_{u}^{2}\right)$.

It is equal to the sum of the $\sigma^{2}$ random variable or the random error variance $\sigma_{v}^{2}$ and the variance of the technical inefficiency $\sigma_{u}^{2}[25$, p. 5].

$$
\sigma^{2}=\sigma_{v}^{2}+\sigma_{u}^{2}
$$


The $\gamma$ value measuring the significance of the stochastic frontier estimation indicates that inefficiency is resulted from random error or technical inefficiency. This is formulated as follows

$$
\gamma=\frac{\sigma_{u}^{2}}{\sigma_{u}^{2}+\sigma_{v}^{2}}=\frac{\sigma_{u}^{2}}{\sigma^{2}} .
$$

The t statistics, which indicate whether the obtained estimation results confirm the null hypothesis, were developed by R.A. Fisher, J.R. Newman and P. Pearson before 1960`s [24, p. 141]. The estimation results of both methods were analysed using related computer programs. The significance levels of the estimation values were given as $p \leq(0.01), p \leq(0.05), p \leq(0.10)$. Most importantly, the values equal to or less than 0.05 indicate that they have a determining role in increasing efficiency.

\section{Variables and Hypotheses}

The Commonwealth of Independent States (CIS) was founded in 1991 after the dissolution of the Union of Soviet Socialist Republics (USSR). The member countries are Azerbaijan, Belarus, Armenia, Kazakhstan, Kyrgyzstan, Moldova, Uzbekistan, Russia, Tajikistan, Turkmenistan and Ukraine. Turkmenistan resigned its full membership status in 2005 and changed its CIS standing to observer member ${ }^{1}$.

In the study, we attempted to determine efficiency with the help of Stochastic Frontier Analysis method by using the data of CIS countries for the period from 2010 to 2015 . The data for the studies were obtained from the statistics sites of the CIS $S^{2}$ and the World Bank ${ }^{3}$. Based on the data, we created regression equations for Cobb-Douglas production function. Methods of Least Squares and Maximum Likelihood Estimation were used for the analyses.

In addition, we attempted to collect data from the websites of the statistical institutions of all countries. Since the necessary data could not be obtained from the websites of the statistical institutions of the Republics of Uzbekistan and Turkmenistan, the data of the CIS statistical institution and the World Bank were used. When comparing the data obtained from the statistical institutions of other countries with the statistics of the CIS and the World Bank, we discovered that the data were the same.

While selecting the variables used in the study, we reviewed related sites were reviewed getting

\footnotetext{
${ }^{1}$ http://www.cisstat.com/ (Date of access: 26.05.2018).

${ }^{2}$ http://www.cisstat.com/ (Date of access: 26.05.2018).

${ }^{3}$ https://data.worldbank.org/ (Date of access: 28.05.2018).
}

access to the data for all countries. In the study we used the following variables: life expectancy at birth, morbidity rate, mortality rate, infant mortality rate and child mortality rate.

The following regression equations are created with the data obtained:

1. $\ln M=\beta_{0}+\beta_{1} \ln B+\beta_{2} \ln D+\beta_{3} \ln P+v_{i}-u_{i}$.

2. $\ln L=\beta_{0}+\beta_{1} \ln B+\beta_{2} \ln D+\beta_{3} \ln P+v_{i}-u_{i}$.

3. $\ln T=\beta_{0}+\beta_{1} \ln B+\beta_{2} \ln D+\beta_{3} \ln P+v_{i}-u_{i}$.

Where $M$ is the value of under-five mortality (probability of dying by age 5 per 1000 live births), $L$ - Life Expectancy at Birth, $T$ - incidence of tuberculosis (100000 population per year), $B-$ Number of hospital beds (per ten thousand people), $D$ - Number of Doctors (per ten thousand people), $P$ - Number of Medical personnel (per ten thousand people). Log-transformed variables were assessed in the regression equation.

The hypotheses researched in the study were as follows:

$\mathrm{HO}: \beta_{0}=\beta_{1}=\beta_{2}=\beta_{3}=0 ;$

$\mathrm{H} 1$ : minimum one parameter $\neq 0$.

Table 1 shows the correlation values and significance levels between the variables (life expectancy at birth, incidence of tuberculosis, under-five mortality rate, and number of hospital beds, doctors and nurses) for the years 2010 to 2015. The corresponding data for all CIS countries per each cited year were used. It is seen that there was a statistically positive and significant correlation between such variables as the number of beds, doctors and personnel, and a statistically negative and significant correlation between the under five-year mortality rate and number of beds, doctor and personnel. It was found that there was a statistically significant and negative correlation between tuberculosis and life variables in the years 2010 and 2012. The correlation values taken were significant above $70 \%$ and at the significance level of $5 \%$. It was observed that the correlation between the other variables was very close to 0,0 and less than 0 , and insignificant at the significance level of $5 \%$. If the value of the correlation coefficients is positive, it demonstrates that there is a correlation in the right direction; a negative value shows the reverse direction. The correlation coefficient equal 0 means that there is no correlation between two variables.

\section{Efficiency Analysis (Results)}

Before interpreting the estimations obtained from the regression, it is necessary to acknowledge some important assumptions related to the linear regression model. These assumptions are whether there are a multicollinearity (Variance Inflation Factor - VIF) between the independent 
Table 1

Correlation between Variables (By Years)

\begin{tabular}{|c|c|c|c|c|c|c|}
\hline 2010 & $\ln B$ & $\ln D$ & $\ln P$ & $\ln L$ & $\ln T$ & $\ln M$ \\
\hline $\ln B$ & 1.0 & & & & & \\
\hline $\ln D$ & $0.66^{*}$ & 1.00 & & & & \\
\hline $\ln P$ & $0.76^{*}$ & $0.69^{*}$ & 1.00 & & & \\
\hline $\ln L$ & -0.25 & 0.46 & -0.08 & 1.00 & & \\
\hline $\ln T$ & -0.08 & -0.58 & -0.33 & $-0.72^{*}$ & 1.00 & \\
\hline $\ln M$ & $-0.79^{* *}$ & $-0.87^{* *}$ & $-0.71^{*}$ & -0.26 & 0.53 & 1.00 \\
\hline 2011 & $\ln B$ & $\ln D$ & $\ln P$ & $\ln L$ & $\ln T$ & $\ln M$ \\
\hline $\ln B$ & 1 & & & & & \\
\hline $\ln D$ & $0.68^{*}$ & 1 & & & & \\
\hline $\ln P$ & $0.77^{* *}$ & $0.69^{*}$ & 1 & & & \\
\hline $\ln L$ & -0.27 & 0.42 & -0.21 & 1 & & \\
\hline $\ln T$ & -0.11 & -0.54 & -0.29 & -0.52 & 1 & \\
\hline $\ln M$ & $-0.81^{* *}$ & $-0.88^{* *}$ & $-0.72^{*}$ & -0.23 & 0.55 & 1 \\
\hline 2012 & $\ln B$ & $\ln D$ & $\ln P$ & $\ln L$ & $\ln T$ & $\ln M$ \\
\hline $\ln B$ & 1 & & & & & \\
\hline $\ln D$ & $0.69^{*}$ & 1 & & & & \\
\hline $\ln P$ & $0.75^{*}$ & $0.67^{*}$ & 1 & & & \\
\hline $\ln L$ & -0.09 & 0.51 & -0.12 & 1 & & \\
\hline $\ln T$ & -0.11 & -0.56 & -0.26 & $-0.66^{*}$ & 1 & \\
\hline $\ln M$ & $-0.86^{* *}$ & $-0.88^{* *}$ & $-0.74^{*}$ & -0.33 & 0.43 & 1 \\
\hline 2013 & $\ln B$ & $\ln D$ & $\ln P$ & $\ln L$ & $\ln T$ & $\ln M$ \\
\hline $\ln B$ & 1 & & & & & \\
\hline $\ln D$ & $0.64^{*}$ & 1 & & & & \\
\hline $\ln P$ & $0.72^{*}$ & 0.56 & 1 & & & \\
\hline $\ln L$ & -0.16 & 0.41 & -0.25 & 1 & & \\
\hline $\ln T$ & -0.18 & -0.46 & -0.33 & -0.42 & 1 & \\
\hline $\ln M$ & $-0.83^{* *}$ & $-0.75^{*}$ & $-0.75^{*}$ & -0.25 & 0.43 & 1 \\
\hline 2014 & $\ln B$ & $\ln D$ & $\ln P$ & $\ln L$ & $\ln T$ & $\ln M$ \\
\hline $\ln B$ & 1 & & & & & \\
\hline $\ln D$ & $0.66^{*}$ & 1 & & & & \\
\hline $\ln P$ & $0.68^{*}$ & 0.49 & 1 & & & \\
\hline $\ln L$ & -0.10 & 0.44 & -0.27 & 1 & & \\
\hline $\ln T$ & -0.227 & -0.524 & -0.393 & -0.467 & 1 & \\
\hline $\ln M$ & $-0.838^{* *}$ & $-0.763^{*}$ & $-0.747^{*}$ & -0.234 & 0.429 & \\
\hline 2015 & $\ln B$ & $\ln D$ & $\ln P$ & $\ln L$ & $\ln T$ & $\ln M$ \\
\hline $\ln B$ & 1 & & & & & \\
\hline $\ln D$ & $0.66^{*}$ & 1 & & & & \\
\hline $\ln P$ & $0.68^{*}$ & 0.47 & 1 & & & \\
\hline $\ln L$ & -0.0 & 0.50 & -0.28 & 1 & & \\
\hline $\ln T$ & -0.20 & -0.58 & -0.33 & -0.53 & 1 & \\
\hline $\ln M$ & $-0.84^{* *}$ & $-0.79^{* *}$ & $-0.75^{*}$ & -0.26 & 0.40 & 1 \\
\hline
\end{tabular}

* Correlation is significant at 0.05 level. ${ }^{* *}$ Correlation is significant at 0.01 level.

variables, the heteroscedasticity problem for the term ui, and the autocorrelation relationship between the disruptive terms. If one of these problems exists, it makes the estimation results of the regression equation difficult or even impossible.

As seen from Table 2, results of the DurbinWatson Test performed using the data for the years 2013, 2014 and 2015 in which " $\ln T$ " was the dependent variable and " $\ln B$ ", $\ln D$ " and " $\ln P$ " were the independent variables demonstrated that there was a different variance problem in analysis of the considered regressions. Therefore, the analyses of these regressions were not interpreted. No other problem was encountered in other regressions.

In the case where the value of $n \times R^{2}$, obtained as a result of the White test regression conducted for the years 2010-2015, is greater than the $X^{2}$ table value, it is accepted that there is a different variance problem. In case the value is smaller, there will be the same variance. In the equations with dependent variables of " $\ln D$ " " $\ln P$ " and " $\ln B$ " and with independent variables of " $\ln L ", " \ln M$ " and " $\ln T$ ", it is accepted that there is a different variance problem.

Because the values of variance inflation factor obtained from the equations with independent variables of " $\ln D$ ", " $\ln P$ " and " $\ln B$ " and with the dependent variables of " $\ln L$ ", " $\ln M$ " and " $\ln T$ " are less than 5 , it was concluded that there was no perfect multiple linearity between the independent variables in regression.

In table 3, we used the dependent variable " $\ln M$ ". The table also demonstrates that in the $L S$ estimations made using Cobb-Douglas production function, only for " $\ln D$ " in 2010, 2011 and 2015, and for " $\ln B$ " and " $\ln D$ " in 2012 , t values of $\beta$ coefficients of independent variables' logarithmic values were greater than $| \pm 2|$ and $p$ likelihood values were found to be less than the significance level of $5 \%$. In 2013 and 2014, it was found that the coefficients obtained by independent variables in the regression were insignificant. The other noteworthy case was that the independent variable " $\ln P$ " was insignificant at the significance level of $5 \%$ in all years, thus, it had no effect on the change of the dependent variable. According to the results of the $L S$ estimation, in the years 2010, 2011, 2012 and 2015 the $1 \%$ increase in the "number of doctors per 10.000 people" may cause an approximate 1-1.4\% decrease in the under-five mortality rate, which is a probability of dying by age 5 per 1000 live births, that is a dependent variable. In 2012, it was estimated that the dependent variable could decrease by $0.89 \%$ as a result of $1 \%$ increase in the number of hospital beds per ten thousand people.

In regressions for all the years, the $R^{2}$ value in the range of $0.8-0.9$ and the adjusted $R^{2}$ values in the range of $0.7-0.8$ demonstrate that approximately $80-90 \%$ of the total change in the dependent variable is explained by the change in the independent variables. The fact that the suf- 
Accuracy of Regression Tests

\begin{tabular}{|c|c|c|c|c|c|c|}
\hline & 2010 & 2011 & 2012 & 2013 & 2014 & 2015 \\
\hline \multicolumn{7}{|c|}{ Dependent variable: $\ln M$ rate } \\
\hline VIF & 1.95 & 1.99 & 2.20 & 3.20 & 2.20 & 2.22 \\
\hline White Test & 10 & 10 & 10 & 10 & 10 & 10 \\
\hline Durbin-Watson Test & $\begin{array}{c}2.062 \\
\text { Agreed }\end{array}$ & $\begin{array}{c}1.997 \\
\text { Agreed }\end{array}$ & $\begin{array}{c}1.963 \\
\text { Agreed }\end{array}$ & $\begin{array}{c}1.801 \\
\text { Agreed }\end{array}$ & $\begin{array}{c}1.812 \\
\text { Agreed }\end{array}$ & $\begin{array}{c}1.817 \\
\text { Agreed }\end{array}$ \\
\hline \multicolumn{7}{|c|}{ Dependent Variable: $\ln L$ expectancy } \\
\hline VIF & 2.1 & 2.01 & 2.50 & 3.50 & 2.50 & 2.42 \\
\hline White Test & 10 & 10 & 10 & 10 & 10 & 10 \\
\hline Durbin-Watson Test & $\begin{array}{c}2.21 \\
\text { Agreed }\end{array}$ & $\begin{array}{c}1.877 \\
\text { Agreed }\end{array}$ & $\begin{array}{c}2.027 \\
\text { Agreed }\end{array}$ & $\begin{array}{c}1.725 \\
\text { Agreed }\end{array}$ & $\begin{array}{c}1.641 \\
\text { Uncertain }\end{array}$ & $\begin{array}{c}1.841 \\
\text { Agreed }\end{array}$ \\
\hline \multicolumn{7}{|c|}{ Dependent Variable: $\ln T$} \\
\hline VIF & 1.98 & 2.12 & 2.34 & 3.34 & 2.34 & 2.24 \\
\hline White Test & 10 & 10 & 10 & 10 & 10 & 10 \\
\hline Durbin-Watson Test & $\begin{array}{c}2.029 \\
\text { Agreed }\end{array}$ & $\begin{array}{c}2.107 \\
\text { Agreed }\end{array}$ & $\begin{array}{c}1.700 \\
\text { Agreed }\end{array}$ & $\begin{array}{c}1.156 \\
\text { Ret }\end{array}$ & $\begin{array}{c}1.188 \\
\text { Ret }\end{array}$ & $\begin{array}{c}1.283 \\
\text { Ret }\end{array}$ \\
\hline
\end{tabular}

Efficiency Estimate Results of Least Squares $(L S)$ and Maximum Likelihood $(M L)$

Table 3 (dependent variable $\ln M-$ under-five mortality rate)

\begin{tabular}{|c|c|c|c|c|c|c|}
\hline & 2010 & 2011 & 2012 & 2013 & 2014 & 2015 \\
\hline Constant (LS) & $\begin{array}{c}10,61^{* * *} \\
(7.04)\end{array}$ & $\begin{array}{c}10.91^{* * *} \\
(7.49)\end{array}$ & $\begin{array}{c}11.16^{* * *} \\
(8.58)\end{array}$ & $\begin{array}{c}12.04^{* * *} \\
(6.26)\end{array}$ & $\begin{array}{c}12.71^{* * *} \\
(6.81)\end{array}$ & $\begin{array}{c}12.81^{* * *} \\
(7.52)\end{array}$ \\
\hline $\ln B(L S)$ & $\begin{array}{c}-0.76 \\
(-1.52) \\
\end{array}$ & $\begin{array}{c}-0.79 \\
(-1.61) \\
\end{array}$ & $\begin{array}{c}-0.89^{*} \\
(-2.01) \\
\end{array}$ & $\begin{array}{c}-0.97 \\
(-1.47) \\
\end{array}$ & $\begin{array}{c}-0.987 \\
(-1.5) \\
\end{array}$ & $\begin{array}{c}-0.91 \\
(-1.48) \\
\end{array}$ \\
\hline $\ln D(L S)$ & $\begin{array}{c}-1.30^{* *} \\
(2.60)\end{array}$ & $\begin{array}{c}-1.36^{* *} \\
(2.67)\end{array}$ & $\begin{array}{l}-1.16^{* *} \\
(-2.68)\end{array}$ & $\begin{array}{c}-0.80 \\
(-1.37) \\
\end{array}$ & $\begin{array}{c}-0.84 \\
(-1.53) \\
\end{array}$ & $\begin{array}{l}-1.00^{*} \\
(-2.01)\end{array}$ \\
\hline $\ln P(L S)$ & $\begin{array}{c}0.05 \\
(0.09)\end{array}$ & $\begin{array}{c}0.03 \\
(0.06) \\
\end{array}$ & $\begin{array}{c}-0.11 \\
(-0.24)\end{array}$ & $\begin{array}{c}-0.56 \\
(-0.95)\end{array}$ & $\begin{array}{l}-0.676 \\
(-1.31)\end{array}$ & $\begin{array}{c}-0.66 \\
(-1,42)\end{array}$ \\
\hline $\log$ Likelihood & $-0.938^{* * *}$ & $-0.432^{* * *}$ & $0.83^{* * *}$ & $1.703^{* * *}$ & $1.66^{* * *}$ & $2.47^{* * *}$ \\
\hline$R^{2}$ & 0.84 & 0.86 & 0.89 & 0.80 & 0.83 & 0.86 \\
\hline Adjusted. $R^{2}$ & 0.76 & 0.78 & 0.83 & 0.70 & 0.74 & 0.79 \\
\hline Est. Std. Error & 0.34 & 0.33 & 0.29 & 0.39 & 0.36 & 0.33 \\
\hline$F$ statistics & $10.35^{* * *}$ & $11.85^{* * *}$ & $15.99^{* * *}$ & $7.88^{* *}$ & $9.64^{* * *}$ & $11.92^{* * *}$ \\
\hline Constant $(M L)$ & $\begin{array}{c}10.61^{* * *} \\
(7.12)\end{array}$ & $\begin{array}{c}10.94^{* * *} \\
(3.69) \\
\end{array}$ & $\begin{array}{c}11.16^{* * *} \\
(7.91)\end{array}$ & $\begin{array}{c}12.36^{* * *} \\
(1.8 \mathrm{e}+05)\end{array}$ & $\begin{array}{l}13.56^{* * *} \\
(18.13)\end{array}$ & $\begin{array}{l}13.71^{* * *} \\
(17.82) \\
\end{array}$ \\
\hline $\ln B(M L)$ & $\begin{array}{l}-0.76^{* *} \\
(-1.96) \\
\end{array}$ & $\begin{array}{l}-0.79^{* *} \\
(-2.08)\end{array}$ & $\begin{array}{l}-0.89^{* * *} \\
(-2.59)\end{array}$ & $\begin{array}{l}-1.32^{* * *} \\
(-57000)\end{array}$ & $\begin{array}{l}-1.37^{* * *} \\
(-2.86)\end{array}$ & $\begin{array}{l}-1.13^{* * *} \\
(-2.62)\end{array}$ \\
\hline $\ln D(M L)$ & $\begin{array}{l}-1.30^{* * *} \\
(-3.36)\end{array}$ & $\begin{array}{l}-1.36^{* * *} \\
(-3.43)\end{array}$ & $\begin{array}{l}-1.16^{* * *} \\
(-3.46)\end{array}$ & $\begin{array}{c}-0.36^{* * *} \\
(-14000)\end{array}$ & $\begin{array}{c}-0.36 \\
(-0.64) \\
\end{array}$ & $\begin{array}{c}-0.67 \\
(-1.26) \\
\end{array}$ \\
\hline $\ln P(M L)$ & $\begin{array}{c}0.05 \\
(0.91) \\
\end{array}$ & $\begin{array}{c}0.03 \\
(0.94) \\
\end{array}$ & $\begin{array}{c}-0.11 \\
(-0.31)\end{array}$ & $\begin{array}{c}-0.60^{* * *} \\
(-42000)\end{array}$ & $\begin{array}{l}-0.84^{* * *} \\
(-5.46)\end{array}$ & $\begin{array}{l}-0.87^{* * *} \\
(-6.51)\end{array}$ \\
\hline$\sigma_{v}$ & 0.266 & 0.25 & 0.22 & 0.000 & 0.000 & 0.000 \\
\hline$\sigma_{u}$ & 0.003 & 0.04 & 0.01 & 0.408 & 0.410 & 0.38 \\
\hline$\sigma^{2}$ & 0.071 & 0.06 & 0.05 & 0.17 & 0.17 & 0.14 \\
\hline$\gamma$ & 0.0001 & 0.02 & 0.0006 & 1.00 & 1.00 & 1.00 \\
\hline$\lambda$ & 0.012 & 0.16 & 0.025 & 83500000 & 4.851 .227 & 2.952 .596 \\
\hline
\end{tabular}

${ }^{*} p \leq 0.10 ;{ }^{* *} p \leq 0.05 ;{ }^{* * *} p \leq 0.01 ; t$ values are given in brackets.

ficiently high value of F-statistic and significance level of $5 \%$ shows that the regression model is estimated correctly.

Table 3 shows that all the inefficiencies in the years of 2010-2012 are caused by random er- ror, while in 2013-2015 in the rate of $100 \%$ they are caused by the technical inefficiency in the Maximum Likelihood Estimation analysis. This can be estimated from the values that $\sigma_{v}, \sigma_{u}, \sigma^{2}$ and y have taken over the years. As a result of the 
$M L$ regression, it is seen that the coefficient value of the "lnB" independent variable is significant at the significance level of $5 \%$ in all years. In this case, it is estimated that $1 \%$ increase in the number of hospital beds per ten thousand people results in the possibility of $0.76-1.37 \%$ decrease in the under-five mortality rate.

In Table 3, in the Maximum Likelihood Estimation, " $\ln D$ " was found to be negatively significant in 2010-2013, while independent variables " $\ln P$ " were found to be negatively significant at the significance level of $1 \%$ in 2013-2015. In 2013, it was estimated that all three independent variables had a negatively significant effect on the dependent variable. This fact suggests that the number of doctors, personnel and hospital beds should be increased in order to reduce the under-five mortality rate.

In Table 4 we used the dependent variable " $\ln L$ ". This table shows that in the $L S$ estimations performed using the Cobb-Douglas production function, for " $\ln B$ " in 2010 and 2011, for " $\ln D$ " and in 2010-2015, and for "lnP” in 2011, $t$ values of $\beta$ coefficients of independent variables' logarithmic values were greater than $| \pm 2|$ and $p$ likelihood values were found to be less than the significance level of $5 \%$. This result can represent the positive effect of the number of doctors on the increase of life expectancy at birth. It can be said that the life expectancy at birth will increase by $1 \%$ because of increase in the number of doctors per ten thousand people by $1 \%$. It is estimated that increase in the number of hospital beds (2010 (-0.06), 2011 $(-0.05)$ and the number of medical personnel (2011 (-0.04)) by $1 \%$ will result in negative interaction on life expectancy.

In regressions for all the years, the $R^{2}$ value in the range of 0.6-0.86 and the adjusted $R^{2}$ values in the range of $0.35-0.78$ show that approximately $60-86 \%$ of the total change in the dependent variable is explained by the change in the independent variables. The fact that the sufficiently high value of $F$-statistic for the data in the period of 2010-2012 and significance level of $5 \%$ shows that the regression model in the mentioned years is estimated correctly. However, low values in 2013-2014 and insignificant level of 5 \% show that the model is estimated incorrectly.

Table 4 demonstrates that all the inefficiencies in the years of 2010-2012 are caused by the technical inefficiency, while in 2013-2015 approximately in the rate of $100 \%$ they are caused by random error in the Maximum Likelihood Estimation analysis. This can be estimated from the values that $\sigma_{v}, \sigma_{u}, \sigma^{2}$ and $y$ have taken over the years. The ML regression reveals that the coefficient value of the dependent variable and " $\ln D$ " independent variable are significant at the significance level of $5 \%$ in all years. In this case, it is estimated that $1 \%$ increase in the number of doctors per ten thousand people results in the possible $1 \%$ increase in life expectancy. In the Maximum Likelihood Estimation, " $\ln B$ " was found to be negatively significant in 2010-2011, while "ln $P$ " independent variables were found to be negatively significant at the significance level of $5 \%$ in 20132015. In 2010 and 2011, it was estimated that all three independent variables had a significant effect on the dependent variable at the significance level of $5 \%$.

Estimations made using the $L S$ method (in Table 5) demonstrate negatively significant correlation at the level of $10 \%$ in 2010, 2012, and 2015 among the $\beta$ coefficients of the logarithmic values of " $\ln T$ " dependent variable and " $\ln D$ " independent variables. This result illustrates that in these years the number of doctors per ten thousand people has a positive effect on the decrease of incidence of tuberculosis per 100.000 populations. In general, the low value of $F$-statistic in all the years and the significance level of $5 \%$ suggest that the regression was insignificant.

Approximately $40-50 \%$ of the $R^{2}$ values and approximately $13-30 \%$ of the adjusted $R^{2}$ values indicate that the very low rate of change in the dependent variable is due to the independent variables.

Table 5 shows that, as a result of Maximum Likelihood analysis, all of the occurred inefficiencies are caused by random error as it takes values very close to 0 in all regressions. This means that the ML results are identical to the LS results. According to the results, for decreasing the incidence of tuberculosis, it is required to increase the number of doctors; however, the number of medical personnel and the change in the number of hospital beds are not important.

\section{Result and Discussion (Conclusions)}

The paper demonstrates the lack of studies, which measure and compare the efficiency of health sectors of the countries of the Commonwealth of Independent States. The lack of consistent international data with the CIS being quite inactive as an international organization, as well as the existence of political, economic and military disagreements between some of the member countries make it difficult to create data flows and conduct analysis. Although there has been a considerable improvement in the data flow between the CIS countries over the past few years, including the establishment of an institu- 
Efficiency Estimate Results of $L S$ and $M L$ (dependent variable $\ln L$ - Life Expectancy at Birth)

\begin{tabular}{|c|c|c|c|c|c|c|}
\hline Variables & 2010 & 2011 & 2012 & 2013 & 2014 & 2015 \\
\hline Constant $(L S)$ & $\begin{array}{c}4.24^{* * *} \\
(65.41)\end{array}$ & $\begin{array}{l}4.26^{* * *} \\
(82.81)\end{array}$ & $\begin{array}{c}4.25^{* * *} \\
(62.88)\end{array}$ & $\begin{array}{c}4.28^{* * *} \\
(47.67)\end{array}$ & $\begin{array}{c}4.28^{* * *} \\
(45.92)\end{array}$ & $\begin{array}{c}4.26^{* * *} \\
(49.35)\end{array}$ \\
\hline $\ln B(L S)$ & $\begin{array}{l}-0.06^{* *} \\
(-2.74)\end{array}$ & $\begin{array}{l}-0.05^{* *} \\
(-2.88)\end{array}$ & $\begin{array}{c}-0.04 \\
(-1.69)\end{array}$ & $\begin{array}{c}-0.03 \\
(-1.01)\end{array}$ & $\begin{array}{c}-0.03 \\
(-0.95)\end{array}$ & $\begin{array}{c}-0.03 \\
(-0.82)\end{array}$ \\
\hline $\ln D(L S)$ & $\begin{array}{l}0.10^{* * *} \\
(4.43)\end{array}$ & $\begin{array}{c}0.10^{* * *} \\
(5.7)\end{array}$ & $\begin{array}{l}0.10^{* * *} \\
(4.32)\end{array}$ & $\begin{array}{l}0.07^{* *} \\
(2.7)\end{array}$ & $\begin{array}{l}0.07^{* *} \\
(2.58)\end{array}$ & $\begin{array}{l}0.07^{* *} \\
(2.85)\end{array}$ \\
\hline $\ln P(L S)$ & $\begin{array}{c}-0.02 \\
(-0.90)\end{array}$ & $\begin{array}{l}-0.04^{*} \\
(-2.07)\end{array}$ & $\begin{array}{c}-0.04 \\
(-1.71)\end{array}$ & $\begin{array}{c}-0.03 \\
(-1.24)\end{array}$ & $\begin{array}{c}-0.03 \\
(-1.23)\end{array}$ & $\begin{array}{l}-0.03 \\
(-1.45)\end{array}$ \\
\hline log Likelihood & $33.5^{* * *}$ & $35.96^{* * *}$ & $32.8^{* * *}$ & $28.4^{* * *}$ & $28.5^{* * *}$ & $29.2^{* * *}$ \\
\hline$R^{2}$ & 0.79 & 0.86 & 0.76 & 0.58 & 0.57 & 0.62 \\
\hline Adjusted. $R^{2}$ & 0.68 & 0.78 & 0.64 & 0.37 & 0.35 & 0.43 \\
\hline Est. Std. Error & 0.02 & 0.12 & 0.02 & 0.02 & 0.02 & 0.02 \\
\hline$F$ statistics & $7.38^{* *}$ & $11.82^{* * *}$ & $6.33^{*}$ & 2.74 & 2.61 & $3.29^{*}$ \\
\hline Constant $(M L)$ & $\begin{array}{c}4.19^{* * *} \\
(650000)\end{array}$ & $\begin{array}{c}4.24^{* * *} \\
(276.70)\end{array}$ & $\begin{array}{c}4.17^{* * *} \\
(190000)\end{array}$ & $\begin{array}{c}4.28^{* * *} \\
(56.63)\end{array}$ & $\begin{array}{c}4.28^{* * *} \\
(56.63)\end{array}$ & $\begin{array}{l}4.26^{* * *} \\
(59.75) \\
\end{array}$ \\
\hline $\ln B(M L)$ & $\begin{array}{c}-0.04^{* * *} \\
(-13000)\end{array}$ & $\begin{array}{l}-0.04^{* *} \\
(-2.35)\end{array}$ & $\begin{array}{c}-0.02 \\
(-1.69)\end{array}$ & $\begin{array}{l}-0.03 \\
(-1.3)\end{array}$ & $\begin{array}{c}-0.03 \\
(-1.23)\end{array}$ & $\begin{array}{c}-0.03 \\
(-1.06)\end{array}$ \\
\hline $\ln D(M L)$ & $\begin{array}{c}0.10^{* * *} \\
(-13000)\end{array}$ & $\begin{array}{c}0.11^{* *} \\
(-2.35)\end{array}$ & $\begin{array}{l}0.11^{* * *} \\
(4.32)\end{array}$ & $\begin{array}{l}0.07^{* * *} \\
(3.49)\end{array}$ & $\begin{array}{l}0.07^{* * *} \\
(3.33)\end{array}$ & $\begin{array}{l}0.07^{* * *} \\
(3.67)\end{array}$ \\
\hline $\ln P(M L)$ & $\begin{array}{l}-0.03^{* * *} \\
(-7208)\end{array}$ & $\begin{array}{l}-0.05^{* *} \\
(-2.35)\end{array}$ & $\begin{array}{c}-0.04^{* * *} \\
(-6099.9)\end{array}$ & $\begin{array}{c}-0.03 \\
(-1.61)\end{array}$ & $\begin{array}{c}-0.03 \\
(-1.59)\end{array}$ & $\begin{array}{l}-0.03^{*} \\
(-1.87)\end{array}$ \\
\hline$\sigma_{v}$ & 0.00 & 0.000 & 0.000 & 0.014 & 0.014 & 0.01 \\
\hline$\sigma_{u}$ & 0.017 & 0.013 & 0.018 & 0.0003 & 0.0003 & 0.0003 \\
\hline$\sigma^{2}$ & 0.0002 & 0.0001 & 0.0003 & 0.0002 & 0.0002 & 0.0002 \\
\hline$\gamma$ & 0.999 & 0.999 & 1.00 & 0.0005 & 0.0006 & 0.001 \\
\hline$\lambda$ & 5.784 .515 & 9.88 & 3.98 & 0.023 & 0.023 & 0.024 \\
\hline
\end{tabular}

${ }^{*} p \leq 0.10 ;{ }^{* *} p \leq 0.05 ;{ }^{* * *} p \leq 0.01 ; t$ values are given in brackets.

Table 5

Efficiency Estimate Results of $L S$ and $M L$ (dependent variable $\ln T$ )

\begin{tabular}{|c|c|c|c|c|c|c|}
\hline Variables & $\mathbf{2 0 1 0}$ & $\mathbf{2 0 1 1}$ & $\mathbf{2 0 1 2}$ & $\mathbf{2 0 1 3}$ & $\mathbf{2 0 1 4}$ & $\mathbf{2 0 1 5}$ \\
\hline \multirow{2}{*}{ Constant $(L S)$} & $6.01^{* * *}$ & $6.17^{* * *}$ & $5.90^{* * *}$ & $6.08^{* * *}$ & $6.32^{* * *}$ & $6.37^{* * *}$ \\
& $(5.54)$ & $(4.75)$ & $(4.72)$ & $(4.13)$ & $(4.46)$ & $(4.37)$ \\
\hline \multirow{2}{*}{$\ln B(L S)$} & 0.55 & 0.48 & 0.50 & 0.36 & 0.45 & 0.58 \\
& $(-1.52)$ & $(1.10)$ & $(1.19)$ & $(0.72)$ & $(0.9)$ & $(1.11)$ \\
\hline \multirow{2}{*}{$\ln D(L S)$} & $-0.75^{*}$ & -0.82 & $-0.85^{*}$ & -0.53 & -0.62 & $-0.84^{*}$ \\
& $(-2.08)$ & $(-1.79)$ & $(-2.05)$ & $(-1.18)$ & $(-1.48)$ & $(-1.95)$ \\
\hline \multirow{2}{*}{$\ln P(L S)$} & -0.23 & -0.14 & -0.09 & -0.27 & -0.35 & -0.32 \\
& $(-0.57)$ & $(-0.30)$ & $(-0.21)$ & $(-0.61)$ & $(-0.89)$ & $(-0.79)$ \\
\hline $\log$ Likelihood & $2.34^{* * *}$ & $0.703^{*}$ & $1.23^{* *}$ & 0.44 & 1.28 & $0.961^{* *}$ \\
\hline$R^{2}$ & 0.52 & 0.42 & 0.46 & 0.28 & 0.38 & 0.46 \\
\hline Adjust. $R^{2}$ & 0.29 & 0.13 & 0.19 & -0.076 & 0.07 & 0.18 \\
\hline Est. Std. Error & 0.25 & 0.29 & 0.28 & 0.30 & 0.28 & 0.28 \\
\hline$F$ statistics & 0.19 & 1.45 & 1.72 & 0.79 & 1.24 & 1.67 \\
\hline \multirow{2}{*}{ Constant $(M L)$} & $6.01^{* * *}$ & $6.20^{* * *}$ & $5.90^{* * *}$ & $6.08^{* * *}$ & $6.33^{* * *}$ & $6.41^{* * *}$ \\
& $(4.94)$ & $(3.18)$ & $(4.14)$ & $(4.13)$ & $(4.22)$ & $(3.22)$ \\
\hline \multirow{2}{*}{$\ln B(M L)$} & $0.55^{* *}$ & 0.48 & 0.50 & 0.36 & 0.45 & 0.58 \\
& $(-1.96)$ & $(1.42)$ & $(1.54)$ & $(0.93)$ & $(1.17)$ & $(1.42)$ \\
\hline \multirow{2}{*}{$\ln D(M L)$} & $-0.75^{* * *}$ & $-0.82^{* *}$ & $-0.85^{* * *}$ & -0.53 & $-0.62^{*}$ & $-0.84^{* *}$ \\
& $(-2.68)$ & $(-2.3)$ & $(-2.65)$ & $(-1.52)$ & $(-1.91)$ & $(-2.48)$ \\
\hline
\end{tabular}


The end of Table 5 on next page

\begin{tabular}{|c|c|c|c|c|c|c|}
\hline Variables & $\mathbf{2 0 1 0}$ & $\mathbf{2 0 1 1}$ & $\mathbf{2 0 1 2}$ & $\mathbf{2 0 1 3}$ & $\mathbf{2 0 1 4}$ & $\mathbf{2 0 1 5}$ \\
\hline $\ln P(M L)$ & $\begin{array}{c}-0.23 \\
(-0.73)\end{array}$ & $\begin{array}{c}-0.14 \\
(-0.39)\end{array}$ & $\begin{array}{c}-0.09 \\
(-0.27)\end{array}$ & $\begin{array}{c}-0.27 \\
(-0.79)\end{array}$ & $\begin{array}{c}-0.35 \\
(-1.15)\end{array}$ & $\begin{array}{c}-0.32 \\
(-1.01)\end{array}$ \\
\hline$\sigma_{v}$ & 0.191 & 0.22 & 0.21 & 0.232 & 0.21 & 0.22 \\
\hline$\sigma_{u}$ & 0.005 & 0.04 & 0.01 & 0.004 & 0.01 & 0.06 \\
\hline$\sigma^{2}$ & 0.037 & 0.05 & 0.05 & 0.054 & 0.05 & 0.05 \\
\hline$\gamma$ & 0.001 & 0.04 & 0.0006 & 0.0003 & 0.001 & 0.065 \\
\hline$\lambda$ & 0.027 & 0.198 & 0.03 & 0.02 & 0.04 & 0.26 \\
\hline
\end{tabular}

$p \leq 0.10 ;{ }^{* *} p \leq 0.05 ;{ }^{* * *} p \leq 0.01 ; t$ values are given in brackets.

tion in the field of statistics in the CIS, some limitations remain. Moreover, the lack of studies focused on the functioning of the health sector, the resources allocated and the effective use of resources, the inconsistency in creating and reporting international standards can be caused by the fact that data for some countries do not cover all the hospitals. Further attempts to collect reliable micro- and macro data in the future and to use of these data for the purpose of academic researches should be encouraged.

In the study, we empirically analysed whether there is a long-term correlation between the resources allocated to health (independent variables) and the health indicators (dependent variables). Independent variables include the number of doctors per ten thousand people, the number of medical personnel per ten thousand people, the number of hospital beds per ten thousand people. Dependent variables are life expectancy at birth, under-five mortality rate, incidence of tuberculosis. The regression analysis was conducted based on the annual data of the Commonwealth of Independent States for the period from 2010 to 2015. We determined the level of correlation between the variables, perfect multiple linearity between independent variables, successive dependency between different variance and disruptive terms, whether or not the problem of auto-correlation is in question.

Then, we assessed the effect of health resources on health indicators the methods of least squares and maximum likelihood estimation of Stochastic Frontier Analysis. The empirical findings determined a negative correlation between the under-five mortality rate and the number of doctors, hospital beds and medical personnel. Additionally, they revealed a positive correlation between the life expectancy at birth, the number of doctors and a negatively significant correlation between the incidence of tuberculosis and the number of doctors.

As a result of this analysis, determination of a statistically significant relationship between the variables in this study can be interpreted in terms of both econometrics and production policy of health services. The dependent and independent variables in econometric studies and the used analysis methods can be effective for finding out different results.

On the other hand, the rate of public health expenditures in GDP in the CIS countries in the period from 2010 to 2015 is approximately $3 \%$; this value can be effective in obtaining the current results. For all CIS countries, we would recommend to popularize the health insurance, to change the old Soviet form of health management in public hospitals, and to implement liberal socio-economic policies. In addition, the public should use health investments in more efficient and productive areas.

Inputs used to measure efficiencies in the healthcare systems of the Commonwealth of Independent States countries in the study conducted by Salamov and Yeşilyurt [16] in 2019 are the number of beds, the number of doctors, the ratio of health expenditures to GDP. Incidence of tuberculosis and under-five mortality rate years are outputs. The input-oriented, fixed-scale CCR model revealed full efficiency scores for Belarus, Armenia and Moldova in 2010 and 2011; for Belarus and Armenia in 2012 and 2014; for Belarus, Armenia, Kazakhstan and Azerbaijan in 2013; and for Belarus, Armenia and Kazakhstan in 2015. The input-oriented, variable-scale BCC model demonstrated full efficiency scores for Belarus, Armenia, Kazakhstan, Moldova, Azerbaijan and Kyrgyzstan in 2010; for Belarus, Armenia, Kazakhstan and Moldova in 2011; for Belarus, Armenia, Kazakhstan, Moldova, Azerbaijan and Tajikistan in 2012 and 2014; for Belarus, Armenia, Kazakhstan, Azerbaijan and Tajikistan in 2013; and for Belarus, Armenia, Kazakhstan, Moldova, Azerbaijan, Tajikistan and Kyrgyzstan in 2015. It was concluded that in the countries that do not have a full efficiency score, there are idle resources, and the incidence of tuberculosis and under-five mortality rate should be lower. Reforms in health policies are needed for more efficient and productive use of resources. 
Reliability of parametric efficiency estimates is very important in terms of deCISion-making in health policy. Researchers and policy makers should be aware of the limitations and inaccuracies of parametric techniques for com- paring health efficiency based on the total data. However, the selectively conducted quantitative international comparison can create valuable source of data that can serve as a basis for further policies.

\section{References}

1. Dastan, I. \& Cetinkaya, V. (2015). Comparing Health Systems, Health Expenditures and Health Indicators in OECD Countries and Turkey. Journal of Social Security, 5(1), 104-134.

2. Kutlar, A., Yuksel F. \& Bakırcı F. (2011). Türkiye’de Belediyelerin Ekonomik Etkinliği ve Etkinliğe Etki Eden Faktörler Üzerine Bir Araștırma. [A Study on Factors Affecting Economic Efficiency and Effectiveness of Municipalities in Turkey]. Ankara: Korza, 374. (In Turk.)

3. Farrell, M. J. (1957). The Measurement of Productive Efficiency. Journal of the Royal Statistical Society: Series A (General), 120, 253-281.

4. Aigner, D. \& Chu S. F. (1968). On Estimating the Industry Production Function, American Economic Review, 58, $826-839$.

5. Seitz, W. D. (1971). Productive Efficiency in the Steam-Electric Generating Industry. The Journal of Political Economy, $79,878-886$.

6. Timmer, C. P. (1971). Using A Probabilistic Frontier Production Function to Measure Technical Efficiency. Journal of Political Economy, 79, 776-794.

7. Afriat, S. N. (1972). Efficiency Estimation of Production Functions. International Economic Review, 13, 568-598.

8. Richmond, J. (1974). Estimating the Efficiency of Production. International Economic Review, 15, 515-521.

9. Avcı T. \& Caglar A. (2016). Stokastik Sınır Analizi: İstanbul Sanayi Odası̉na Kayıtlı Firmalara Yönelik Bir Uygulama [Stochastic Frontier Analysis: An Application Toward The Firms Registered For Istanbul Industry Chamber]. SEYAD, 4(2), 17-57. (In Turk.)

10. Sadokhina, E. Y. (2003). Makroekonomicheskaya Otsenka Effektivnosti Natsionalnogo Proizvodstva Stran SNG v 1991-2001 gg [CIS Members National Production Efficiency Estimation. Macroeconomic Aspects]. Nauchnye Trudy: Institut Narodnokhozyaystvennogo Prognozirovaniya RAN [Scientific Articles - Institute of Economic Forecasting Russian Academy of Sciences], 1, 309-325. (In Russ.)

11. Loukoianova E. \& Unigovskaya A. (2004). Analysis of Recent Growth in Low-Income CIS Countries. IMF Working Paper, WP/04/151, 39.

12. Semionova, E. \& Mitryuk M. (2017). Analiz stokhasticheskoy granitsy kak metod otsenki urovnya razvitiya krestyanskikh fermerskikh khozyaystv v respublike Moldova [Stochastic Frontier Analysis as the Evaluation Method of the Rural Development Level of Peasant Farms in the Republic of Moldova]. Studia Universitatis Moldaviae, 7(107), 127-135. (In Russ.)

13. Bakhtin, K. (2009). Otsenka i sravnenie tekhnicheskoy effektivnosti rossiyskikh promyshlennykh i torgovykh kompaniy [The Measurement and the Comparison of Technical Efficiency of Russian Manufacturing and Trade Companies]. Working Paper - Moscow: New Economic School, 42. (In Russ.)

14. Silvestrov, S. N., Bauer, V. P. \& Eremin, V. V. (2018). Otsenka zavisimosti multiplikatora investitsiy ot izmeneniya struktury ekonomiki regiona [Estimation of the Dependence of the Investment Multiplier on the Structure of the Regional Economy]. Ekonomika regiona [Economy of Region], 14(4), 1463-1476. DOI: https://doi.org/10.17059/2018-4-31. (In Russ.)

15. Salamov F., Turgut Ișık T. \& Koç P. (2018). BDT ülkelerinin sağllk sistemlerine etkinlik analizleri Düzeylerinin [Analysis of the Activity Levels of Health Systems in CIS Countries]. In: D. Köksal (Ed.), II. Uluslararası Eğitim Bilimleri ve Sosyal Bilimler Sempozyumu [Conference Proceedings, II. International Symposium of Educational Sciences and Social Sciences] (pp. 505-512). (In Turk.)

16. Salamov F. \& Yeşilyurt Ö. (2019). Bağımsız Devletler Topluluğu Ülkeleri Sağlık Sistemlerinde Etkinlik Analizi [Efficiency Analysis of Health Systems in Community of Independent States Countries]. In: VI. Uluslararası Türk Dünyası Araştırmaları Sempozyumu Bildiriler Kitabı CILT II [Conference Proceedings, VI. International Research Symposium on the Turkic World. Part II] (pp. 151- 160). (In Turk.)

17. Aigner, D., Knox-Lovell C. A. \& Schmidt P. (1977). Formulation and Estımation of Stochastic Frontier Production Function Yöntems. North-Holland Publishing Company Journal of Econometrics, 6, 21-37.

18. Meeusen, W \& Broeck J. v. D. (1977). Efficiency Estimation from Cobb-Douglas Production Functions with Composed Error. International Economic Review, 18(2), 435-444.

19. Cooper, W. W. \& Tone K. (1997). Measures of Inefficiency in Data Envelopment Analysis and Stochastic Frontier Estimation. European Journal of Operational Research, 99, 72-88.

20. Baltagi, B. H. (2005). Econometric Analysis of Panel Data, 3rd Edition. New York: John Wiley, 228.

21. Chen, C.-M., Delmas, M. A. \& Lieberman, M. B. (2015). Production Frontier Methodologies and Efficiency as a Performance Measure in Strategic Management Research, Strategic Management Journal, 36, 19-36 
22. Battese, G. E. \& Coelli, T. J. (1992). Frontier Production Functions, Technical Efficiency and Panel Data: With Application to Paddy Farmers in India. The Journal of Productivity Analysis, 3, 153-169.

23. Mohan, R. \& Mirmirani, S. (2007-2008). An Assessment of OECD Health Care System Using Panel Data Analysis. Southwest Business and Economics Journal, 16, 21-35.

24. Kutlar, A. (2012). Ekonometriye Giriş [Introduction to Econometrics]. Ankara: Nobel, 588.

25. Coelli, T. J. (1996). A Guide to Frontier Version 4.1: A Computer Program for Stochastic Frontier Production and Cost Function Estimation. CEPA Working Papers, 7/96, 33.

\section{Authors}

Ozgur Yesilyurt - PhD in Management, Assistant Professor, Department of Health Management, Faculty of Health Sciences, Muş Alparslan University; ORCID: http://orcid.org/0000-0001-9252-3375 (Güzeltepe, MŞU, 49250, Muş, Turkey; e-mail: o.yesilyurt@alparslan.edu.tr).

Fuad Selamzade - (corresponding author) PhD Economics, Assistant Professor, Department of Health Management, Faculty of Health Sciences, Muş Alparslan University; ORCID: http://orcid.org/0000-0002-2436-8948 (Güzeltepe, MŞU, 49250, Muş, Turkey; e-mail: f.salamov@alparslan.edu.tr). 